\title{
IR Game -tiedonhakupelistä oppimisympäristön osana
}

\author{
Kai Halttunen \\ Operationaalisissa tiedonhakujärjestelmissä, kuten \\ tietokannoissa ja www-hakupalveluissa, hakijan on \\ mahdotonta arvioida luotettavasti, kuinka hyvin hän on \\ omassa hakutehtävässään onnistunut. Järjestelmillä, \\ jotka antavat palautetta haun onnistumisesta, voidaan \\ avata tiedonhakujärjestelmien toimintaperiaatteita ja \\ osoittaa konkreettisesti, miten erilaisten tiedonhaun \\ ilmiöiden huomioonottaminen vaikuttaa tiedonhaun \\ onnistumiseen.
}

Tietoverkkojen leviäminen tutkimusyhteisöistä kansalaisten jokapäiväiseksi informaatioympäristöksi on tuonut tiedonhaun, tiedon tallennuksen ja tiedonhankinnan kysymykset entistä näkyvämmän mielenkiinnon kohteiksi. Tiedonhankinnan ja -haun katsotaan - ainakin erilaisissa tietoyhteiskuntahankkeissa - kuuluvan kansalaisten moderniin medialukutaitoon. Tiedonhankinta ja -haku on yhä keskeisempää useilla osaamisalueilla ja niille valmentavassa perus- ja jatkokoulutuksessa. Samaan aikaan oppimiskäsityksen sanotaan muuttuneen oppijoiden omaehtoista tiedonhankintaa korostavaksi.

Tiedonhaun (information retrieval) periaatteiden ja menetelmien hallinta on keskeinen informaatioalan ammattilaisten osaamisalue. Tiedonhaun opetus on vakiintunut yliopistoissa, joissa on informaatiotutkimuksen sekä kirjasto- ja tietopalvelualan koulutusta. Tiedonhaun perusteita ja menetelmiä esitteleviä oppikirjoja on ilmestynyt runsaasti (esim. Harter 1986, Hersh 1996, Järvelin 1995, Lancaster \& Warner 1993, Large, Tedd \& Hartley 1999) samoin kuin erilaisia opaskirjoja (esim. Basch 1998, Heikkinen et al. 1998).

Tiedonhaun oppikirjat esittelevät neljä keskeistä tiedonhaun osaamisen aluetta: 1) tiedonhaku osana tiedonhankinnan kokonaisuutta, 2) tiedonhakujärjestelmien toimintaperiaatteet, 3) yleiset tiedonhaun strategiat, jotka ovat sovellettavissa lähes kaikissa tiedonhakujärjestelmissä, 4) erityiset tiedonhakustrategiat, joita voidaan soveltaa tietyssä tiedonhakuympäristössä ja tietokannassa. Koulutuksen tavoitteena on tuottaa sellaista osaamista, mihin tukeutuen voidaan toimia missä tahansa tiedonhakuympäristössä. 
Erilaisissa ympäristöissä käytettäviä hakujärjestelmiä ovat esimerkiksi kirjastojen kokoelmaluettelot, viiteaineistoa tai kokonaisia artikkeleita sisältävät tietokannat ja Internetin tiedonhakupalvelut sekä sanomalehtien teksti- ja kuva-arkistot.

Tietokantojen käytössä voidaan erottaa selkeästi kolme vaihetta. 1970-80 -luvuilla online-tietokannat olivat selkeästi ammattilaisten työkaluja. 1980-luvun puolivälissä CD-ROM -tietokannat siirsivät osan tiedonhausta tiedontarvitsijoiden itsensä tekemäksi. 1990-luvun puolesta välistä alkaen tietoverkot ovat tuoneet tiedonhaun menetelmät ja välineet kansalaisten käyttöön. Monet verkkotiedonhakua käsittelevät tutkimukset paljastavat kuitenkin, että tiedonhaun välineitä käytetään suhteellisen tehottomasti ja yksioikoisesti (Fidel et al. 1999, Jansen, Spink, Saracevic 2000, Spink, Bateman, Jansen 1998, Wang, Hawk, Tenopir 2000). Tiedonhaun perusperiaatteiden omaksumista ja asiantuntemuksen kehittymistä vaikeuttaa usein kiinnittyminen yksittäisten tiedonhakujärjestelmien ominaisuuksiin ilman, että oppijalle muodostuu kokonaiskuvaa tiedonhaun ominaispiirteistä ja haun onnistumiseen vaikuttavista tekijöistä.

Tiedonhaku on moninaista osaamista vaativaa toimintaa, johon kuuluu tiedontarpeiden ja dokumenttien tarkastelu sekä kognitiivisella että lingvistisellä tasolla (Ingwersen 1992). Etsittävät dokumentit ovat tekniseltä kannalta merkkijonojen joukkoja. Kirjoitusmerkeillä esitetään luonnollisen kielen ilmauksia. Luonnollisen kielen ilmaisut puolestaan edustavat dokumenttien käsitteellistä sisältöä. Tiedontarpeita voidaan analysoida vastaavilla tasoilla. (Järvelin 1995, Järvelin \& Sormunen 1999.) Taitava tiedonhakija osaa ottaa huomioon tiedontuottajien mahdolliset erilaiset käsitteelliset näkökulmat ja erilaiset ilmaisut käyttämilleen käsitteille. Hakijan on myös pystyttävä ymmärtämään ja vaikuttamaan tiedonhakuohjelmiston tapaan käsitellä ilmaisuja merkkijonoina eli hakijan on pystyttävä rakentamaan tarkoituksenmukaisia kyselyjä. Lisäksi on osattava valita relevantteja tiedonlähteitä, tietokantoja, joista haku on tarkoituksenmukaista suorittaa. Tiedonhaun perusongelmia ovat mm. luon- nollisen kielen ominaisuudet (monitulkintaisuus, sanojen ja niiden vartaloiden taipuminen, yhdyssanat ja sanaliitot sekä johdokset), tiedonhaun käsitteellinen suunnittelu, vaihtoehtoisten ilmausten ideointi, kyselyn muotoilu, dokumenttien ja sisällönkuvailun sekä metadatan tuntemus, tiedontuottajien tuntemus, hakutuloksen ja dokumenttien relevanssin arviointi suhteessa tiedon tarpeeseen. Tiedonhaku on lähes aina kytkeytyneenä eriluontoisten tehtävien suorittamiseen ja on siten aito ongelmanratkaisutilanne.

Edellä kuvattujen tiedonhaun ilmiöiden analysointi ja tiedonhaun muokkaaminen siten, että saavutetaan entistä parempia tuloksia, edellyttää pitkälle menevää kokemusta ja osaamista. Operationaalisissa tiedonhakujärjestelmissä (tietokannat, www-hakupalvelut) hakijan on kuitenkin mahdotonta arvioida luotettavasti, kuinka hyvin hän on omassa hakutehtävässään onnistunut. Järjestelmillä, jotka antavat palautetta haun onnistumisesta, voidaan avata tiedonhakujärjestelmien toimintaperiaatteita ja osoittaa konkreettisesti, miten erilaisten tiedonhaun ilmiöiden huomioonottaminen vaikuttaa tiedonhaun onnistumiseen.

Tutkimus kuvaa ja arvioi Tampereen yliopiston informaatiotutkimuksen laitoksella kehitetyn tiedonhakututkimuksen ja opetuksen välineen, IR Game - tiedonhakupelin (Sormunen et al. 1998), prototyypin käytettävyyttä tiedonhaun opetuksessa. Tarkoituksena on saada kokonaiskuva, vaikutelma Tiedonhakupelin käytöstä tietyssä oppimistilanteessa. Tutkimuksessa saatava tieto auttaa kehittämään Tiedonhakupeliä edel- 
leen ja tarjoaa ideoita laajemman tiedonhaun oppimisympäristön kehittämiseen. Tavoitteena on myös määrittää IR Game:n asemaa oppimisympäristökeskustelussa ja tutkimuksessa. Tiedonhaun perusilmiöiden ymmärtämistä tukevia oppimisympäristöjä ei ole aiemmin kehitetty ja tutkittu.

Tiedonhaun oppimista käsittelevää tutkimustakin on tehty hyvin vähän. Suurin osa tehdystä tutkimuksesta keskittyy tiedonhankintataitojen analysointiin ja ohjaukseen (Kuhlthau 1988, 1991, 1993, 1996) sekä tiedonhaun ohjaukseen kirjastojen käyttäjäkoulutuksen yhteydessä. Viime aikoina on jonkin verran keskusteltu oppimisesta digitaalisissa kirjastoissa (esim. Jacobson \& Ignacio 1997, Kuhlthau 1997, Neuman 1997). Informaatiotutkimuksessa on tarkasteltu jonkin verran oppimistyylien vaikutusta tiedonhakijoiden toimintaan (esim. Borgman 1989, Davis \& Davis 1990, Logan 1990, Saracevic \& Kantor 1988). Tietokoneavusteisen opetuksen keinoja tiedonhaun yhteydessä on tarkasteltu lähinnä 1970-80-luvun vaihteessa, kun tiedonhaun asiantuntijoita opetettiin käyttämään tuolloin vielä harvinaisia ja kalliita online-tietokantoja. Nämä sovellukset olivat erilaisia simulaatioita ja tutoriaaleja, jotka ohjasivat ja harjaannuttivat tietyn tiedonhakujärjestelmän tehokkaaseen käyttöön. (esim. Caruso 1978, 1979, 1981, Chapman 1981, Griffith \& Norton 1981, Meadow, Aversa \& Hewett 1982, Stirling 1984). Edellä kuvattu tutkimus ja kehitystyö keskittyi pitkälti operationaalisten järjestelmien toimintaan eikä niillä pyritty tiedonhaun peruskäsitteiden ja ilmiöiden opettamiseen. Opetusohjelmien jälkeen kehittyivät tiedonhaun tuki-, asiantuntija- ja välittäjäjärjestelmät (vrt. Drenth, Morris \& Gwyneth 1991).

\section{Käsityksiä op pi misy m pärist öistä}

Oppimisympäristö on terminä nuori; se yleistyi 1980-luvun lopulla (Pantzar 1998, 99-100). Oppimisympäristö-käsitteelle on löydettävissä useita määritelmiä ja usein se esiintyy hyvinkin epämääräisenä, annettuna käsitteenä tai sitä käy- tetään modernina iskusanana (Land \& Hannafin 2000, Manninen 2000, Manninen \& Pesonen 1997, Pantzar 1995, 86-88, Wilson 1996).

Laajimmassa merkityksessä oppimisympäristöllä voidaan tarkoittaa mitä tahansa ympäristöä, jossa oppimista tapahtuu. Jos hyväksytään jaottelu informaaliin, nonformaaliin ja formaaliin oppimiseen, voidaan informaalin oppimisen osalta nähdä oppimisympäristönä koko ihmisen elämänpiiri. Hieman rajatummassa katsannossa kansalaisen mediamaisema kokonaisuudessaan voidaan määritellä oppimisympäristöksi. Maisemassa ovat edustettuna yhtälaisesti yksilöllisen viestinnän, ryhmäviestinnän ja joukkoviestinnän sanomat sekä niiden tarkoitukset ja välineet.

Tietoverkot palveluineen esitetään usein myös itsessään oppimisympäristönä. Tämä tulkinta on mahdollinen vain sellaisessa tilanteessa, jossa oppimisympäristön käsitettä käytetään sen laajimmassa merkityksessä tietynlaisena tieto- ja viestintäteknologisena elämänpiirinä. Internet tarjoaa toki resursseja, dokumentteja, kontakteja ja viestintämahdollisuuksia, mutta sitä ei kuitenkaan voi sijoittaa tieto- ja viestintätekniikkaa hyödyntäviin oppimisympäristöihin (Land \& Hannfin 2000).

Toisaalta oppimisympäristöllä saatetaan tarkoittaa fyysisten tilojen ja palveluiden muodostamia kokonaisuuksia: esimerkiksi koulun, kirjaston ja tietoverkon voidaan ajatella muodostavan avoimen oppimisympäristön, jossa oppimiselle on olemassa resursseja, tukitoimintoja ja ohjausta. Perkinsin (1991) mukaan kaikki oppimisympäristöt koostuvat 1) tiedonlähteistä (information sources), 2) symbolien ja kielen manipulointija tallennusvälineistä (symbol pads), 3) kohteista ja välineistä (phenomenaria), joiden avulla voidaan havainnoida, manipuloida ja esittää opittavia ilmiöitä, 4) esitys- ja rakentelutyökaluista (construction kits) sekä 5) toimintaa ohjaavista tekijöistä (task managers), kuten ohjaajat, oppimistehtävät ja kanssaoppijat. Collins, Brown ja Newman (1989) ovat esittäneet ideaalin oppimisympäristön elementtejä. Heidän tarkastelunsa pohjautuu kognitiivisen mestari-oppipoika -oppimisen ja tilannesidonnaisen op- 
pimisen malleihin. Heidän näkemyksensä mukaan oppimisympäristö rakentuu sisällön, metodien, ajoituksen ja sosiaalisten tekijöiden sisällöstä ja niiden välisistä suhteista.

Tieto- ja viestintätekniikkaa hyödyntävät oppimisympäristöt on mahdollista erottaa yleisestä oppimisympäristökeskustelusta. Kokonaisuuden hahmottaminen on tällä rajatummallakin osa-alueella hankalaa, koska erilaiset yksittäiset oppimisympäristöhankkeet perustuvat hyvin erilaisiin teoreettisiin lähtökohtiin ja toteutustapoihin. Keskustelua hankaloittaa toisaalta tarkasteltavien ilmiöiden epäselvyys, yleistettävyyden ongelmat ja toisaalta tarkastelunäkökulmien ja tutkimusmenetelmien puutteet. Aluetta voidaan myös tarkastella tietokoneavusteisen opetuksen tai tieto- ja viestintätekniikkaa hyödyntävän etäja monimuoto-opetuksen näkökulmasta (vrt. Tella 1997, Collis 1996). Teknologiaperustaisten ympäristöjen ääripäinä voidaan pitää verkostopohjaisia, konstruktivismiin perustuvia oppimisympäristöjä ja informaatioteknologian hyödyntämistä tavalla, joka tukeutuu ohjelmoidun opetuksen behavioristiseen traditioon (Hannafin, Land \& Oliver 1999).

Moderneissa teknologiaperustaisissa oppimisympäristöissä on tunnistettavissa ainakin neljä suuntausta, jotka esiintyvät usein vuorovaikutuksessa keskenään. Yhteisöllinen oppiminen on näiden ympäristöjen keskeinen elementti. Nämä ympäristöt, esimerkiksi CSILE, KnowledgeForum, FLE ja Workmates, perustuvat usein tiedon rakenteluun (Hakkarainen 1997, Hakkarainen, Lonka \& Lipponen 1999, Scardamalia \& Bereiter 1994), kognitiiviseen mestari-oppipoika -oppimiseen (Collins, Brown \& Newman 1989), vastavuoroiseen opetukseen (Palinscar \& Brown 1984) ja jaettuun asiantuntemukseen (Resnick, Levine \& Teasley 1991). Toisena suuntauksena voi pitää erilaista simulaatioita ja pienoismaailmoja. Näissä sovelluksissa oppijat voivat rakentaa, mallintaa, manipuloida ja tutkia erilaisia opittavia ilmiöitä, joiden käsittely olisi muuten hyvin hankalaa tai joissakin tapauksissa jopa mahdotonta. Tällaisia ympäristöjä ovat esimerkiksi Model-IT, joka mahdollistaa laadullisten mallien rakentelun luonnonilmiöistä (Jackson, Stradford,
Krajcik \& Soloway 2000) ja ALEL, joka tarjoaa opiskelijoille simuloidun ympäristön kokeelliseen tutkimukseen (Lehtinen \& Rui 1996). Kiinnostuksen kohteena on ollut myös oppimisen ankkuroiminen todellisen maailman monimutkaisiin ongelmiin (Cognition and Technology Group at Vanderbilt 1990, 1992) sekä hajautettu asiantuntijuus (Bell \& Winn 2000) ja näkemys tilannesidonnaisesta kognitiosta (Lave 1991, Wilson \& Myers 2000).

Tietoteknologiaperustaisia oppimisympäristöjä tulisi pitää kokonaisuuksina, missä yhdistyvät muiden muassa teknologia, toiminnat, tavoitteet, oppimistilanne, ohjaajan ja oppijan roolit, jotka saavat aikaan yhteisvaikutuksen. IR Game tiedonhakupelin prototyypissä on tunnistettavissa joitakin teknologiaperustaisen oppimisympäristöjen piirteitä, kuten tiedonhaun ilmiöiden simulointi, manipulointi ja tutkiminen. Käytettävät tiedonhakujärjestelmät ja tietokannat ovat aitoja, todellisen maailman järjestelmiä, jotka on varustettu ilmiöiden havainnollistamista helpottavilla työkaluilla. Näitä työkaluja voidaan käyttää myös palautteen antamiseen kyselyjen onnistumisesta samoin kuin pelimäisten ominaisuuksien, esimerkiksi hakujen vertailun esittämiseen. Perkinsin (1991) kategorioita mukaillen prototyyppi tarjoaa tiedonhaun oppimiseen kohteet ja välineet (phenomenaria) sekä esitysja rakentelutyökalut (construction kits). Tiedonhakupeliä ei voi kuitenkaan nykyisessä prototyyppivaiheessa kutsua oppimisympäristöksi, vaan ennemminkin työkaluksi, jonka ympärille tulee kehittää toimintoja ja pedagogisia ratkaisuja. Ainoastaan tämän jatkokehitystyön jälkeen tarjolla on ehkä todellinen tiedonhaun oppimisympäristö.

\section{Tiedonhakupeli oppimis- ympäristön osana}

Tampereen yliopiston informaatiotutkimuksen laitoksen tiedonhakupeli kehitettiin alunperin tiedonhaun tutkimuksen tarpeisiin, koska tiedonhaun onnistumista oli työlästä havainnollistaa pelkän tuloslistan perusteella. Tiedonhakupeli automatisoi prosessia piirtämällä saanti- ja 
tarkkuuskäyrät automaattisesti jokaisesta tiedonhausta. Pelin oletettiin soveltuvan myös tiedonhaun opetukseen, koska tiedonhaun opiskelija on samankaltaisessa tilanteessa kuin tutkija. Sekä tutkijan että tiedonhaun opiskelijan tavoitteena on selvittää optimaalisia tapoja tiedonhakuun. Tällä tavoin tiedonhakupelin välitön palaute auttaa opiskelijaa kehittämään hakutaitojaan. Ohjelmaversio 3.0 otettiin opetuskäyttöön 1998, jonka jälkeen sitä on käytetty rutiininomaisesti tiedonhaun opetuksessa.

Tiedonhakupeli koostuu neljästä osasta: 1) joukosta täsmällisiä tiedonhakutehtäviä, joihin täsmääviä dokumentteja etsitään tietokannasta, 2) joukosta relevanssiarvioita, jotka identifioivat kuhunkin hakutehtävään täsmäävät dokumentit, 3) ohjelmistosta, joka välittää tiedonhaut eri tiedonhakujärjestelmiin ja tietokantoihin, 4) palautejärjestelmästä, joka arvioi ja visualisoi kyselyiden onnistumista.

Järjestelmässä hyödynnettäviä resursseja ovat esimerkiksi: 1) 54000 sanomalehtiartikkelin tietokanta, johon liittyy 35 tiedonhakutehtävää ja 17000 relevanssiarviota, 2) puolen miljoonan dokumentin englanninkielinen tietokanta vastaavin tiedonhakutehtävin ja relevanssiarvioin,
3) 15000 kuvan valokuvatietokanta hakutehtävineen ja relevanssiarvioineen, 4) tiedonhakujärjestelmät TRIP (Boolen malli) ja InQuery (probabilistinen malli), 5) ohjelmistot saanti-tarkkuus -tietojen tuottamiseen, 6) sanakirjaohjelmistot (suomi-ruotsi-englanti-saksa) sekä 7) morfologiset analyysiohjelmistot.

IR Game vertaa haussa löytyneiden dokumenttien joukkoa relevanteiksi tiedettyjen joukkoon ja antaa vertailun perusteella palautetta tiedonhaun onnistumisesta. Tiedonhaun tarkoituksena on löytää tiedontarpeeseen ja tiedonhakutehtävään täsmäävät relevantit dokumentit. Relevanssin käsite on informaatiotutkimuksen keskeisimpiä käsitteitä (esim. Cosijn \& Ingwersen 2000, Saracevic 1996, Schamber 1994). Relevanssi voi olla aiherelevanssia, joka tarkoittaa dokumenttien ja hakutehtävän määrittelemää aihetta tai laajemmin käyttäjärelevanssia, jossa huomioidaan aiheen lisäksi tiedon käyttäjästä riippuvia tekijöitä. Näitä tekijöitä ovat esimerkiksi tehtävän luonne, dokumenttien kieli, uutuus, ulkoasu, tuttuus käyttäjälle. Tiedonhakupelissä ja laajemminkin tiedonhaun opetuksessa joudutaan useinmiten tukeutumaan aiherelevanssiin, jotta tiedonhaun onnistumista voitaisiin arvioida.

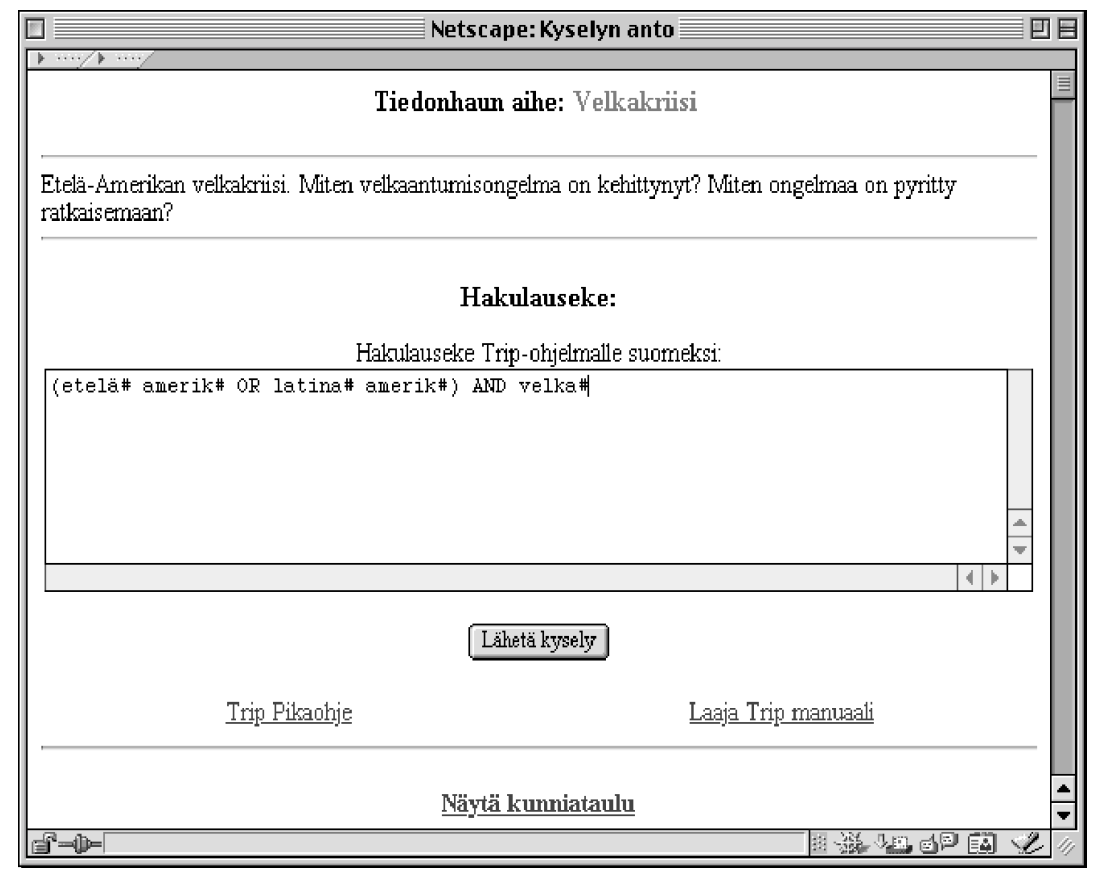

Kuva 1. Kyselyn syöttö tiedonhakupelissä 


\section{A R T I K K E L I T}

Kuva 2.

Kyselyn onnistuminen saantitarkkuus -käyrällä

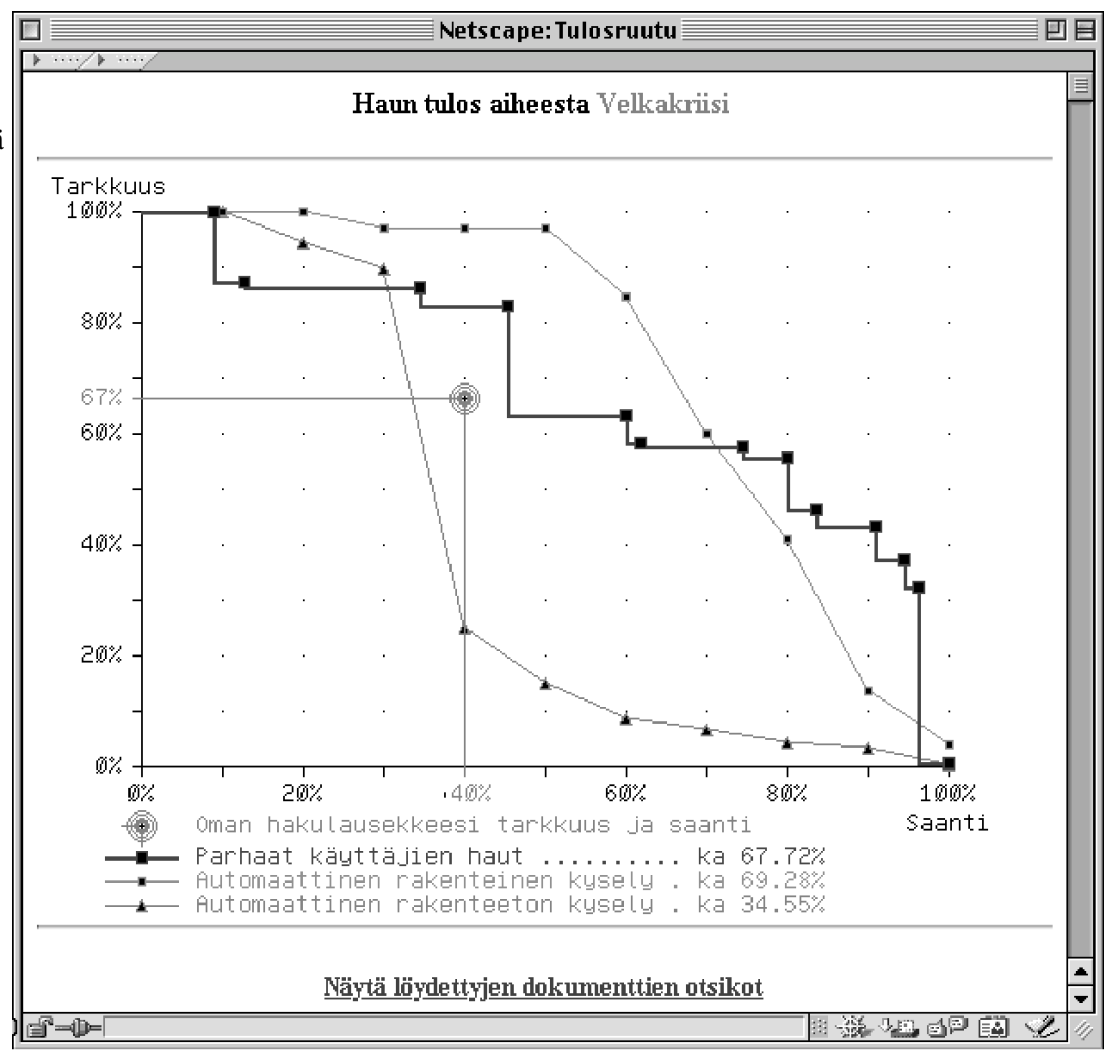

Kuva 3.

Dokumenttien otsikko-, relevanssi- ja sijaintitiedot hakutuloksessa

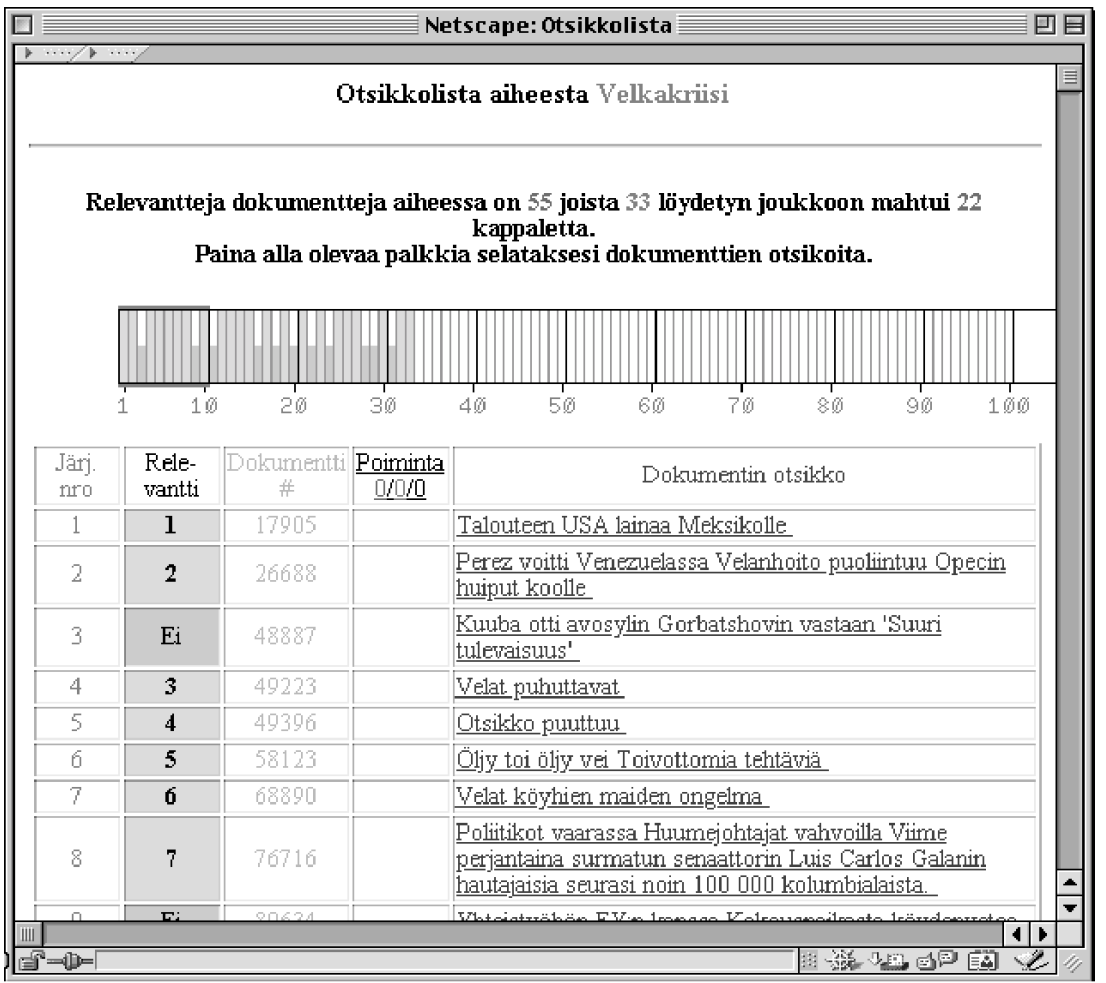


Hakulausekkeen muotoilun (Kuva 1) jälkeen Tiedonhakupeli havainnollistaa hakutuloksen graafisesti esittämällä saanti-tarkkuus -käyrän (Kuva 2). Saanti ja tarkkuus ovat tavallisimmat ja laajimmin käytetyt hakutulosta koskevat arviointikriteerit. Hakutuloksen tarkkuus kuvaa löydettyjen relevanttien dokumenttien osuutta kaikista löydtyistä dokumenteista. Saanti puolestaan kuvaa löydettyjen relevanttien dokumenttien osuutta kaikista tietokannassa olevista relevanteista dokumenteista. Tarkkuus ja saanti esitetään joko desimaalilukuina välillä $[0,1]$ tai prosenttilukuina välillä $0 \ldots 100$. Operationaalisissa tiedonhakujärjestelmissä hakija voi arvioida hakutuloksen tarkkuutta, mutta saantia on mahdotonta arvioida, ellei koko tietokannasta selvitetä jollakin keinoin relevanttien dokumenttien lukumäärää.

Tiedonhakija voi tarkastella löydettyjen dokumenttien otsikoita, relevanssiarvioita sekä relevanttien dokumenttien sijoittumista hakutulokseen (Kuva 3). Hän voi siirtyä myös tutkimaan kokonaisia dokumentteja. Peli näyttää haluttaessa lisäksi hakuvihjeenä löytymättä jääneitä dokumentteja, jotka olisivat olleet relevantteja kyseisessä tehtävässä. Tiedonhakupeli pitää kirjaa käyttäjien parhaiten onnistuneista hauista kunniataululla, ja parhaita hakuja esitetään myös saanti-tarkkuus -käyrällä.

Tiedonhakupeli tarjoaa tiedonhaun oppijalle, opettajalle ja tutkijalle ainutlaatuisen työskentely-ympäristön, jossa voidaan analysoida kyselyiden, tietokantojen ja tiedonhakujärjestelmien vaikutusta tiedonhaun onnistumiseen. Hakutuloksen saannin ja tarkkuuden esittäminen mahdollistaa keskittymisen tiedonhaun onnistumiseen vaikuttavien tekijöiden analysointiin ja testaamiseen - eikä tuloslistojen tarkasteluun. Näiden tietojen avulla voidaan demonstroida kyselyn laajennusten tai hakukäsitteiden valinnan vaikutusta tiedonhaun onnistumiseen. Tiedonhakupeli avaa näiden toimintojen avulla tiedonhakujärjestelmien "mustan laatikon" ja mahdollistaa tehokkaiden tiedonhakustrategioiden ja taktiikoiden testaamisen ja tutkivan oppimisen tietokannoiltaan ja välineiltään aidossa ja monipuolisessa ympäristössä.

\section{Tutkimusongelma}

Tutkimuksessa kuvataan Tiedonhakupelin toiminnallisten mahdollisuuksien hyödyntämistä osana oppimisympäristöä.

Koska pelin opetuskäyttöä ei ole aikaisemmin tutkittu tai evaluoitu, pyrin lähestymään kohdetta mahdollisimman avoimesti ilman tarkkoja hypoteeseja. Tavoitteena on antaa monipuolinen kuva oppijoiden kokemuksista ja näkemyksistä siitä, kuinka käytettävä sovellus on tiedonhaun perusopetuksessa.

Tutkimuskysymykset voidaan asettaa seuraavasti: 1) Miten opiskelijat kokevat Tiedonhakupelin? 2) Mitkä pelin toiminnot koetaan oppimista edistäviksi ja mitkä taas oppimista estäviksi? 3) Miten ohjelmaa voitaisiin kehittää paremmin tiedonhaun oppimista tukevaksi? 4) Millaisia muita elementtejä ohjelmiston tueksi tulisi liittää, jotta voitaisiin puhua todellisesta tiedonhaun oppimisympäristöstä?

\section{Tutkimusmenet elmät ja aineistot}

Tutkimuksen kohteena on pelin käyttö informaatiotutkimuksen perusopintoihin kuuluvalla tiedonhaun perusteiden kurssilla. Kurssi koostuu luennoista (30 h), ohjatuista harjoituksista (6 h) sekä itsenäisesti suoritettavista viikkoharjoituksista (10 vko), jotka opiskelijat suorittavat www:n kautta. Tutkittavalle kurssille osallistui noin 100 henkilöä. Kussakin harjoitusryhmässä oli keskimäärin 10 opiskelijaa.

Tiedonhakupeliä käytettiin kurssilla viidennellä ohjatulla harjoituskerralla. Ohjelman perustoiminnot käytiin läpi edellisellä. Harjoitusten tavoitteena oli tutustuttaa oppijat kuvatiedonhakuun sekä havainnollistaa luennolla esitettyjen tiedonhaun onnistumisen arvioinnin mittareiden, saannin ja tarkkuuden olemusta sekä havainnollistaa hakulausekkeiden muotoilun ja hakutermien valinnan vaikutusta hakutuloksiin. Oppimisympäristö koostui siis tässä tilanteessa ohjatusta luento- ja harjoitusopetuksesta, jaetusta materiaalista, harjoitustehtävistä, Tiedonhakupelistä sekä käytetyistä hakuohjelmistoista ja tietokannoista, 
järjestelmän opasteista (järjestelmän sisäiset ja ohjaajan tekemät opasteet ja ohjeet), tiedonhakutehtävistä ohjeineen sekä harjoitusten ohjaajan kokoavasta palautteesta.

Harjoituskertaa seuraavan viikon luennon aluksi opiskelijat kirjoittivat eläytymismenetelmällä (Eskola 1998) varioitujen kehyskertomusten perusteella omat tarinansa oppimistilanteesta ja oppimiskokemuksistaan. Tutkija esitteli osallistujille menetelmän ja kertasi lyhyesti harjoitustilanteen, johon kertomukset tulisi sitoa. Kirjoittamisaikaa annettiin noin 15-20 minuuttia. Varioidut kehyskertomukset on esitetty liitteessä (Liite 1). Kirjoituksia palautettiin yhteensä 67 kappaletta, joista neljä jouduttiin hylkäämään sisällön rajallisuuden vuoksi. Nämä neljä kertomusta kuvasivat opiskelijaelämän harrastuksia ja niistä johtunutta motivoitumattomuutta ja väsymystä tiedonhakukurssilla. Hyviä oppimiskokemuksia kuvaavia kertomuksia on aineistossa 32 ja huonoja kokemuksia valottavia kertomuksia on 31 kappaletta.

Käytin kirjoitelmia ja varioituja kehyskertomuksia, koska halusin pikemminkin keksiä hypoteeseja kuin testata niitä. Tavoitteena oli, että vastaajat voivat tuottaa vapaasti käsityksensä tutkittavasta asiasta. Menetelmä sopii mielestäni erittäin hyvin esiteltävään tutkimukseen, koska sen kautta saadaan esiin sellaisia käsityksiä ja käytäntöjä, jotka eivät olisi tulleet muilla menetelmillä lainkaan tutkijan tietoisuuteen. Eläytymismenetelmällä tuotettu aineisto muodostaa siis keskeisimmän tutkimusaineistoni.

Saadakseni käsityksen oppimistilanteen kokonaisuudesta ja kertomusten analyysiä helpottavia jäsennyksiä osallistuin havainnoijana luennolle, jossa Tiedonhakupeli esiteltiin opiskelijoille. Havainnoinnin tarkoituksena oli selvittää analysoitavan toiminnan ympäristö ja saada kuva niistä mahdollisista ennakkojäsennyksistä, joita harjoituksiin osallistuvilla opiskelijoilla on. Jatkoin havainnointia neljän ryhmän harjoitustilanteessa niiden käyttäessä Tiedonhakupeliä. Kussakin harjoitusryhmässä olleet 10 opiskelijaa tekivät tiedonhakuja useimmiten kahden-kolmen henkilön ryhmissä. Havainnoinnissa kiinnitin huo- miota seuraaviin tekijöihin: 1) oppimistilanteen ilmapiiri, 2) työskentelytapa (valmistautuminen, pari-yksilötyöskentely, keskustelu harjoitusten aikana), 3) ohjaajalle esitettyjen kysymysten luonne, 4) ohjaajan kommentit ja kysymykset. Havainnoinnin lisäksi kussakin neljässä harjoitusryhmässä tallennettiin video-lokiin Tiedonhakupelin käyttö yhdeltä koneelta.

\section{Aineiston analyysi}

Eläytymismenetelmällä tuotetut kertomukset analysoitiin irrottamalla samaa ilmiötä kuvaavat tekstikokonaisuudet kertomuksista, jonka jälkeen tekstikokonaisuudet sijoitettiin yhdenmukaisuuden perusteella luokkiin. Teemoittelun perusteella rakennettiin kolme pääluokkaa ja viisi alaluokkaa. Analyysiluokat on esitetty taulukossa 1. Oppimiskokemuksia kuvaavat tekstikokonaisuudet luokitettiin vielä uudelleen kolmen kuukauden kuluttua alkuperäisestä luokituksesta. Tässä vaiheessa muutama "ohjatut harjoitukset oppimisympäristönä” -teemaan kuuluneet havainnot luokitettiin uudelleen "tiedonhakupeli opetusohjelmana" -teemaan. Harjoituksissa kerättyä havainnointiaineistoa ja video-lokia käytetään tässä tutkimuksessa ainoastaan varmentamaan tekstiaineistosta tehtyjä tulkintoja.

\section{Tutkimustulokset}

Kuinka opiskelijat kokivat oppimistilanteen ja käyttivät Tiedonhakupelin mahdollisuuksia? Eläytymismenetelmällä kirjoitetuista kertomuksista nousi selvästi esiin kolme teemaa: kertomukset 1) tiedonhakupelistä tietokonesovelluksena, 2) kertomukset tietokannoista ja 3) kertomukset harjoitustilanteesta oppimisympäristönä. Luokitellut teemat on esitetty taulukossa 1.

\section{Tiedonhakupeli tietokonesovelluksena}

Palaute omasta suorituksesta, kyselyn muokkaus ja uudesta hakutuloksesta saatava palaute koettiin yleisesti merkittäväksi. Palautemekanismi mahdollisti huomion kiinnittämisen hakukäsitteiden valintaan, hakulausekkeen sekä hakuter- 


\section{Teema}

Tiedonhakupelitietokonesovelluksena

Palautemekanismi

Hakutulosten visualisointi

Hakujen onnistumisen vertailu muiden hakuihin

Dokumenttien (artikkelit, kuvat) selailu

Vihjetoiminto

Tietokantojen sisältö ja tyyppi
Edistioppimista

Estioppimista

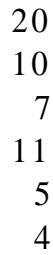

5

2

112

5

4
6
3

Taulukko 1. Eläytymismenetelmäkertomusten luokitellut teemat ja esiintymien lukumäärä

mien muokkaamiseen ja analysointiin, eikä aikaa kulunut omien hakutulosten läpikäyntiin ja arviointiin. Opiskelijoiden mukaan palaute selvensi käsityksiä tiedonhaun ilmiöistä ja hakulausekkeiden muokkauksen vaikutuksista hakutuloksiin. Graafista esitystä pidettiin selvästi parempana kuin numeroarvoina esitettyä tulosta.

Tiedonhaun onnistumisen arvion esittäminen saattaa myös haitata oppimista. Huomio kiintyy tulokseen, jolloin pyritään parantamaan hakutulosta mekaanisesti - ajattelematta ja analysoimatta itse tapahtumaa. Tämä johtaa pinnalliseen selviytymiseen ja pelimäisyyden korostumiseen. Usein koettiin, että tilanteessa syntyvää tietämystä ei pystytä siirtämään todellisuuteen, sellaisiin tilanteisiin, joissa käytetään todellisia tiedonhakujärjestelmiä ilman palautemekanismia. Näissä järjestelmissä tiedonhaun onnistumisen arviointi on tiedonhakijan itsensä tehtävänä.

Mahdollisuus verrata omaa hakutulosta muiden tuloksiin koettiin motivoivana ja kannustavana. Näin syntyi hienoinen kilpailuasetelma ja halu parantaa omaa hakutulosta. Mielenkiintoista on, ettei vertailumahdollisuutta mainittu lainkaan oppimista estävänä tekijänä, vaikka kritiikkiä toisaalta esitettiin juuri huomion kiintymiseen pelkkään hakutulokseen ja sen parantamiseen. Parhaat hakutulokset tallentuivat myös "kunniataululle", joka oli osallistujien nähtävissä, vaikka harjoitusten ohjaaja ei esitellyt eikä kannustanut sen hyödyntämiseen.

Sekä relevanttien että epärelevanttien löydettyjen dokumenttien selailumahdollisuus tuotiin esiin oppimista edistävänä tekijänä muutamissa kertomuksissa. Hakutulosten analysointi ja dokumenttien tutkiminen sekä uusien hakutermien etsiminen edellyttävät kuitenkin oppijalta aktiivisuutta. Moni opiskelija pitikin dokumentteja ulkoasultaan huonoina, vaikeasti hahmotettavina. Video-loki ja havainnointi paljastivat, että dokumenttien selailu ja analysointi saattoi tapahtua myös hyvin pintapuolisesti. Selittävänä tekijänä voi olla se, että ihmiset eivät mielellään lue näytöltä suhteellisen rakenteetonta tekstiä. Selailumotivaatiota alentaa varmasti myös se, ettei dokumenttien lukemisen ensisijaisena tarkoituksena ollut niiden sisältämän informaation omaksuminen, vaan uusien hakusanojen ideointi. Selailussa tutkittiin vain muutamia relevantteja artikkeleita ja poimittiin uusia hakutermejä suhteellisen satunnaisesti. Selailussa korostui osaltaan perustelematon pyrkimys löytää jotain - mitä tahansa, jolla voisi parantaa hakutulosta. Ilmiö korostuu erityisesti käytettäessä osittaistäsmäyttävää tiedonhakujärjestelmää, jossa kysely saattaa olla rakenteeton sanalista.

Järjestelmä tarjoaa “vinkkitoiminnon”, joka näyttää hakutuloksen lisäksi sellaisen relevantiksi määritellyn dokumentin, jota hakija ei ole omalla haullaan löytänyt. Vinkin tarkoituksena on auttaa hakijaa löytämään sellaisia hakutermejä, joilla hakutulosta voisi parantaa. Vinkkitoimintoa pidettiin oppimista edistävänä samaan tapaan kuin dokumenttien selausta. Hieman suuremmassa osassa kertomuksista vinkkiä pidettiin kuitenkin oppimista estävänä tekijänä; vinkin toivottiin olevan enemmänkin opastusta - esimerkiksi hakulausekkeiden muokkausopastusta sekä 
ohjeita siitä, miten haun tarkkuutta ja saantia voisi parantaa. Opastuksen toivottiin integroituvan kiinteästi opiskeltavaan aiheeseen ja tarkasteltaviin ilmiöihin.

\section{Tietokantojen tietosisällön merkitys oppimiskokemuksiin}

Käytettyjä tietokantoja - kotimaisia sanomalehtiartikkeleita sisältävää tietokantaa ja Lehtikuvan kuvatietokantaa - pidettiin oppimista edistävinä, koska ne olivat aitoja, todellisia tietokantoja. Harjoituksissa käytettyjen tietokantojen avulla saavutettu kokemus ja tietämys koettiin mahdolliseksi siirtää todellisiin tiedonhakutilanteisiin. Journalistinen lähestymistapa oli myös osalle opiskelijoista motivoivaa, koska he tulevaisuudessa työskentelevät viestintäalalla. Oppimista edistävänä tekijänä muutama kertojista mainitsi kuvatietokannan eksoottisuuden ja erilaisuuden, koska harjoituskerta oli useille opiskelijoille ensimmäinen kosketus kuvahaun maailmaan.

\section{Ohjatut tiedonhakuharjoi- tukset oppimisympäristönä}

Kaikkein eniten oppimista haittaavia tekijöitä kuvattiin olevan ohjattujen harjoitusten kokonaisuudessa. Nämä moniaalle hajautuvat käsitykset paljastavat hedelmällisellä tavalla oppimisympäristön kompleksisuuden ja monimuotoisuuden sekä ne keskeiset lisäominaisuudet ja pedagogiset ratkaisut, joita tarvitaan kehitettäessä tiedonhaun oppimisympäristöä ja Tiedonhakupelin toiminnallisuutta.

Oppimistilanteen aloituksella ja tiedonhakupeliin valitulla ensimmäisellä tehtävällä on oppimisprosessin kannalta motivoiva ja kiinnostusta herättävä merkitys. Ensimmäinen tehtävä oli suunniteltu suhteellisen helpoksi kuvahakutehtäväksi, jossa opiskelijoiden oletettiin saavuttavan parhaan mahdollisen tuloksen. Osa opiskelijoista saavuttikin tavoitteen: he kertoivat onnistumisen elämyksistä ja siitä, kuinka hyvä ha- kutulos motivoi heitä jatkamaan tiedonhakua. Video-loki ja havainnot osoittavat, että osa opiskelijoista lähestyi yksinkertaiseksi tarkoitettua kuvahakutehtävää liiankin monimutkaisesti soveltaen aiemmin tutuksi tulleita tekstitiedonhaun menetelmiä. Palautteesta huolimatta hakijoiden oli myös vaikea muuttaa lähestymistapaansa tässä tilanteessa.

Ohjaajalta saadut ohjeet, täsmentävät kysymykset ja mahdollisuus kysyä koettiin tärkeäksi. Ohjaajan toiminta korvasi ja täydensi sovelluksen puutteellisia opasteita ja vinkkitoimintoja. Toisaalta ohjaajalla ei ollut aikaa vastata kaikkiin kysymyksiin, ja joskus ohjaajan vastaukset opiskelijan kysymyksiin ja hänen tarjoamansa vihjeet eivät onnistuneet siirtämään oppijan toimintaa ongelmatilanteen yli.

Hakutehtävien aiheiden vieraus ja niiden kiinnostamattomuus esitettiin useissa kertomuksissa oppimista estävinä. Palautejärjestelmän käyttö pakottaa käyttämään tiettyjä ennalta määriteltyjä hakutehtävien aiheita. Tietokannan sisältö koostui 1990-luvun alun uutisartikkeleista, jotka eivät aihepiireiltään liittyneet kovinkaan kiinteästi aloittavien opiskelijoiden kokemusmaailmaan. Hakutehtävien sanallista muotoilua pidettiin myös liian ennaltamäärättynä ja keinotekoisena.

Harjoitusten tekeminen pienryhmissä, ratkaisujen perusteleminen ja keskustelu olivat esillä monissa onnistunutta oppimistilannetta kuvaavissa kertomuksissa. Joissakin kertomuksissa onnistunut oppimisprosessi kuvattiin yksinkertaisena mallina. Esimerkiksi eräs opiskelija mallinsi oppimisprosessiaan seuraavasti:

Onnistuneita oppimiskokemuksia kuvaavissa kertomuksissa järjestelmän antamaa palautetta, löydettyjä dokumentteja ja vinkkitoimintoa hyödynnettiin haun uudelleenmuotoilussa ja tiedonhaun perusilmiöiden analysoinnissa. Aiemman hakulausekkeen ominaisuuksien ja haun tulok-

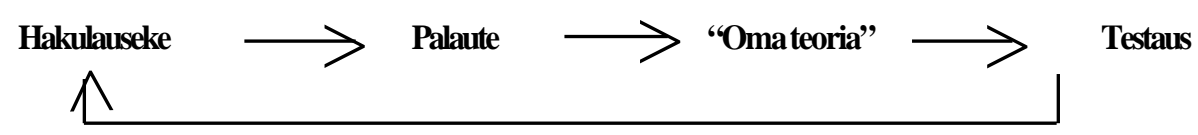


sena saatujen dokumenttien analyysin perusteella muodostettiin "työskentelyteoria" siitä, miten hakutulosta voitaisiin parantaa, esimerkiksi: "Voin parantaa saantia lisāämällä ja yhdistämällä OR-operaattorilla synonyymeja ja käyttämällä katkaisua eli otan huomioon sanojen taipumisen." tai "Koska tämä on sanomalehtijuttuja sisältävä tietokanta, minun tulee ottaa huomioon sanomalehtikieli, siinä käytetään useinmiten erisnimiä, ideoin maiden nimiä hakulausekkeeseeni." Työskentelyteoriaa testattiin uudella haulla. Nimenomaan mahdollisuus aktiivisesti kokeilla ja muokata hakua samoin kuin se, ettei järjestelmä tarjoa liian ohjattua harjoitetta, koettiin oppimista edistävänä.

\section{Johtopäätökset}

Nykyisessä kehitysvaiheessaan IR Game -tiedonhakupeli on uudenlainen työkalu, jota voidaan käyttää tiedonhaun ilmiöiden analysoinnin ja oppimisen välineenä erilaisissa oppimisympäristöissä. IR Game tarjoaa välineitä tiedonhaun ilmiöiden simulointiin, manipulointiin ja tutkimiseen. Käytettävät tiedonhakujärjestelmät ja tietokannat ovat aitoja, todellisen maailman järjestelmiä, jotka on varustettu ilmiöiden havainnollistamista helpottavilla työkaluilla. Näitä työkaluja voidaan käyttää myös palautteen antamiseen kyselyjen onnistumisesta, samoin kuin pelimäisten ominaisuuksien, esimerkiksi hakujen vertailun esittämiseen. Perkinsin (1991) kategorioita mukaillen prototyyppi tarjoaa tiedonhaun oppimiseen kohteet ja välineet (phenomenaria) sekä esitys- ja rakentelutyökalut (construction kits).

Prototyypin käyttäjäevaluaatio toi esiin tekijöitä, jotka on otettava huomioon tiedonhaun oppimisympäristöä kehitettäessä. Tutkimus paljasti, että samat ominaisuudet nähdään niin oppimista edistävinä kuin estävinäkin. Nämä erot saattavat johtua yksittäisen oppijan aiemmasta tietämyksestä, oppimistyylistä ja tiedonhakua koskevista käsityksistä. Oppimistilanteen ja -tehtävien suunnittelu vaikuttaa osaltaan kokemuksiin. IR Game tarjoaa ohjaajalle monia mahdollisuuksia rakentaa erilaisia oppimistilanteita. Ohjaaja voi vaikuttaa palautemekanismiin, tehtävien esitystapaan, pelimäisiin ominaisuuksiin ja opastei- siin sekä oppimistulosten esittämiseen, artikulointiin ja arviointiin. Yksittäiset hakutehtävät ovat riippuvaisia käytetyistä tietokannoista.

Vaikka tiedonhausta saadun palautteen koettiin edistäneen oppimista merkittävästi, saattoi palaute johtaa myös pinnalliseen pelaamiseen ja selviytymiseen. Tavoitteena oli tuolloin ainoastaan hyvä sijoitus saanti-tarkkuus -asteikolla. Tähän ongelmaan voidaan puuttua tehtävien muotoilulla sekä oppijan hakua koskevien valintojen artikuloinnilla ja perustelulla. Pinnallisia selviytymistrategioita voidaan heikentää myös muokkaamalla palautejärjestelmää näkymättömämmäksi tai näkyväksi. On mahdollista, että palautetta ei anneta lainkaan tai sitä annetaan erilaisena tiedonhakuprosessin eri vaiheissa. Löydettyjen dokumenttien selausta ja vinkkitoimintoa tulisi kehittää tilannesidonnaisemmaksi ja interaktiivisemmaksi. Järjestelmä voi toki tarjota laajaakin “älykästä” käyttäjätukea ja ohjausta, joiden avulla käyttäjä saa tehtävät hyväksytysti suoritetuksi. Hyväksyttävä eli hyvä suoritus, ei kuitenkaan takaa oppimisprosessin etenemistä. Opastus-, ohjaus- ja tukijärjestelmien (scaffolding) toteutuksen merkitys onkin teknologiaperustaisen opetuksen keskeinen elementti.

Tietokannat ja niitä kuvaava metainformaatio on keskeinen osa oppimisympäristöä. Todellisen maailman tietokannat ja ajankohtainen sisältö motivoivat oppijaa ja parantavat tiedonhaun ilmiöiden ymmärtämistä erilaisissa tiedonhakuympäristöissä. Tiedonhakupeliin voidaan liittää uusia tietokantoja ja luoda niihin relevanssitiedot. Tieto- ja relevanssikantoja voidaan suunnata erilaisille oppijoille ja aihealueille. Keräilyohjelmien avulla tuotetut tietokannat julkisesta www-aineistosta mahdollistaisivat järjestelmän liittämisen avoimiin oppimisympäristöihin. Nykyään tietokantojen sisältöjen avointa esittämistä on kuitenkin rajoitettu tekijänoikeussopimuksin.

Hakutehtävien täsmällisyys ja vieraus koettiin usein ongelmalliseksi. Oppimis- ja hakutehtävien liittäminen laajempiin kehyskertomuksiin, taustatarinoihin ja todellisiin tilanteisiin (anchored instruction) voisi helpottaa ilmiöiden käsit- 
telyä ja enenevässä määrin lisätä motivaatiota.

Keskustelu ja omien ratkaisujen perustelu oli luonnollisesti tärkeässä osassa monissa onnistuneissa oppimistilanteissa. Tiedonhakupelin prototyyppi ei tue kovin joustavasti omien ratkaisujen perustelua ja esittämistä. Harjoituksissa nämä toiminnot toteutettiin ohjaustilanteessa. Järjestelmä voidaan integroida www-pohjaisiin kommunikaatiotyökaluihin tai siihen voidaan luoda omia välineitä "työskentelyteorioiden" esittämiseen ja kommunikointiin. Omien ratkaisujen perusteleminen ja kommunikointi on selvästi avain oppimistulosten parantamiseen myös Tiedonhakupelissä.

Tiedonhakujärjestelmien kehittämistutkimuksessa on usein esillä näkemys mahdollisimman pitkälle järjestelmän ohjaamasta, käyttäjälle näkymättömästä, toiminnasta. Tiedonhakijalla ei tässä tilanteessa ole paljonkaan keinoja hallita ja ohjata järjestelmän toimintoja; hän voi vain syöttää järjestelmään vaikkapa luonnollisen kielen lauseen tai rakenteettoman sanalistan kuvaamaan tiedontarvettaan. Järjestelmä tuottaa täsmäytys- ja relevanssilajittelualgoritmin avulla tuloslistan. Hakijan voi olla erittäin vaikea päätellä, mihin hakutulos perustuu ja miten kyselyn muokkaus vaikuttaisi tuloksiin. Bates (1990) on pohdiskellut järjestelmän ja käyttäjän suhdetta tiedonhaussa nimenomaan kontrollin näkökulmasta jäsentäen tilanteita, joissa prosessin ohjaus ja toteutus on järkevää toteuttaa joko käyttäjän tai järjestelmän toimin. Tämä neliportainen jäsennys tarjoaa mahdollisen tiedonhakututkimuksen viitekehyksen oppimisympäristön kehittämiseen.

Tiedonhaku on aina osa tiedonhankinnan kokonaisuutta eli aitoa ongelmanratkaisutilannetta ja tehtävän suorittamista. Tällaisessa aidossa tilanteessa tiedonhaun aihe, tiedonlähteet ja tiedonhakujärjestelmät ovat ainutlaatuisia. Näitä uniikkeja tilanteita ei voida mallintaa mihinkään tiedonhaun oppimisympäristöön, mutta se ei tee Tiedonhakupelin kaltaisia välineitä tai tiedonhaun ohjausta ja opastusta silti tarpeettomaksi, koska tiedonhaussakin tarvitaan ymmärrystä alueen ilmiöistä ja niiden soveltamista toimintaan. Ilman tätä osaamista tiedonhaku jää suljetuksi "mustaksi laatikoksi” tai naiiviksi käsitykseksi, että esimerkiksi Internetin hakukoneet ovat kaikkein kehittyneimpiä tiedonhakujärjestelmiä.

Tässä ensimmäisessä, alustavassa käyttäjäevaluaatiossa tavoitteena oli kuvata ja analysoida opiskelijoiden oppimiskokemuksia Tiedonhakupeliä käytettäessä. Tutkimus paljasti monialaisesti tiedonhaun oppimisympäristön kehittämisessä huomioitavia elementtejä. Jatkotutkimus keskittyy ympäristön kehittämiseen näiden tulosten pohjalta sekä oppimistulosten arviointiin.

\section{Lähteet}

BASCH, R. (1998) Researching online for dummies. Foster : IDG Books.

BATES, M. (1990) Where should the person stop and the information search interface start? Information Processing and Management (26):5, 575591.

BELL, P. \& Winn, W. (2000) Distributed cognitions, by nature and design. Julkaisussa: Theoretical foundations of learning environments. ed. by David H. Jonassen \& Susan M. Land. Hillsdale (NJ): Lawrence Erlbaum Associates, s. 123-146.

BORGMAN, C.L. (1989) All users of information retrieval systems are not created equal: an exploration into individual differences. Information Processing and Management (25):3, 237-251.

CARUSO, E. (1978) Online training for searching online. Paper presented at the 2nd International Online Information Meeting. London, 5-7 December.

CARUSO, E. (1979) TRAINER : Computer assisted learning and practice for users of DIALOG/ORBIT. Final report. Pittsburg University, PA.

CARUSO, E. (1981) Computer aids to learning online retrieval. Julkaisussa: Annual Review of information Science and Technology (ARIST). Ed by Martha E. Williams. White Plains: ASIS \& Knowledge Industry Publications, s. 317-336.

CHAPMAN, J. L. (1981) A state transition analysis of online information-seeking behavior. Journal of the American Society for Information Science (32):5, 325-333.

Cognition and Technology Group at Vanderbilt (1990) Anchored instruction and its relationship to situated cognition. Educational Researcher (19):3, 2 10 .

Cognition and Technology Group at Vanderbilt (1992) The Jasper experiment : an exploration of issues in learning and instructional design. Educational Technology Research and Development (40):1, 6580 .

COLLINS, A., Brown, J. S. \& Newman, S. E. (1989) Cognitive apprenticeship : teaching the crafts of reading, writing and mathematics. Julkaisussa: Knowing, learning and instruction : essays in honor of Robert Glaser. Ed. by Lauren B. Resnick. Hillsdale 
(NJ) : Lawrence Erlbaum Associates, s. 453-494.

COLLIS, B. (1996) Tele-learning in a digital world: the future of distance learning. London : International Thompson Computer Press.

COSIJN, E. \& Ingwersen, P. (2000) Dimensions of Relevance. Information Processing and Management (35) [Painossa].

DAVIS, D.L. \& Davis, D.F.(1990) The effects of training techniques and personal characteristics on training end users of information systems. Journal of Management Information Systems (7):2, 93-110.

DRENTH, H., Morris, A. \& Gwyneth, T. (1991) Expert Systems as Information Intermediaries. Julkaisussa: Annual Review of information Science and Technology (ARIST). Ed by Martha E. Williams. Medford: ASIS \& Learned Information, 1991, s. 113-154.

ESKOLA, J. (1998) Eläytymismenetelmä sosiaalitutkimuksen tiedonhankintamenetelmänä. Väitöskirja, Kuopion yliopisto. Tampere : Taju.

FIDEL, R. et al. (1999) A visit to the information mall : web searching behavior of high school students. Journal of the American Society for Information Science (50):1, 24-37.

GRIFFITH, J. C. \& Norton, N. P. (1981) A computer assisted instruction program for end users on an automated information retrieval system. Julkaisussa: National Online Meeting. Proceedings of the Second National Online Meeting, New York, USA, 24-26 March 1981. Medford, NJ. : Learned Information, s. 239-248.

HAKKARAINEN, K. (1997) Verkostoympäristöt ja kognitio. Julkaisussa: Verkkopedagogiikka toimittanut Erno Lehtinen. Helsinki : Edita, s. 60-84.

HAKKARAINEN, K., Lonka, K. \& Lipponen, L. (1999) Tutkiva oppiminen : älykkään toiminnan rajat ja niiden ylittäminen. Helsinki : WSOY.

HANNAFIN, M. J., Land, S. \& Oliver, K. (1999) Open learning environments : foundations, methods, and models. In: Instructional theories and models (Volume II). Ed. by C. Reigeluth. Mahwah, NJ: Erlbaum.

HARTER, S. (1986) Online information retrieval : concepts, principles, and techniques. Orlando : Academic Press.

HEIKKINEN, R. et al. (1998) Tiedonhakijan teho-opas : tiedonhaun peruskirja. Jyväskylä : Teknolit.

HERSH, W. R. (1996) Information retrieval : a health care perspective. New York: Springer.

INGWERSEN, P. (1992) Information retrieval interaction. London : Taylor Graham.

INGWERSEN, P. (1996) Cognitive perspectives of information retrieval interaction: Elements of a cognitive IR theory. Journal of Documentation (32):1, 3-50.

JACOBSON, F. F. \& Ignacio, E. N. (1997) Teaching reflection : information seeking and evaluation in a digital library environment. Library Trends (45):4, 771-802.

JACKSON, S., Stratford, S., Krajcik, J. \& Soloway, E. (2000) Making dynamic modeling accessible to pre-college science students. Interactive Learning Environments. [painossa].

JANSEN, B.J., Spink, A., Saracevic, T. (2000) Real life, real users, and real needs : a study and analysis of user queries on the web. Information Process- ing and Management (36):2, 207-228.

JÄRVELIN, K. (1995) Tekstitiedonhaku tietokannoista : johdatus periaatteisiin ja menetelmiin. Espoo : Suomen atk-kustannus.

JÄRVELIN, K. \& Sormunen, E. (1999) Dokumentit kateissa? : tiedon tallennus ja haku avuksi. Julkaisussa: Tiedon tie : johdatus informaatiotutkimukseen. toim. Ilkka Mäkinen. Helsinki : BTJ-Kirjastopalvelu, s. 110-143.

KUHLTHAU, C. C. (1988) Longitudinal case studies of the search process of users in libraries. Library and Information Science Research (10):3, 257-304.

KUHLTHAU, C. C. (1991) Inside the search process: information seeking from the user's perspective. Journal of the American Society for Information Science (42):5, 361-371.

KUHLTHAU, C.C. (1993) Seeking meaning : a process approach to library and information services. Norwood: Ablex.

KUHLTHAU, C. C. (1996) The concept of a zone of intervention for identifying the role of intermediaries in the information search process. In: Proceedings of the $59^{\text {th }}$ Annual Meeting of the American Society for Information Science, Baltimore, Maryland, October 21-24, 1996. Medford : Information Today. s. 91-94.

KUHLTHAU, C. C. (1997) Learning in digital libraries: an information search process approach. Library Trends (45):4, 708-724.

LANCASTER, F. W. \& Warner, A. J. (1993) Information retrieval today. Arlington: Information Resource Press.

LAND, S. M. \& Hannafin, M.J. (2000) Student-centered learning environments. Julkaisussa: Theoretical foundations of learning environments. ed. by David H. Jonassen \& Susan M. Land. Hillsdale (NJ) : Lawrence Erlbaum Associates, s. 1-23.

LARGE, A., Tedd, L. A. \& Hartley, R. J. (1999) Information seeking in the online age : principles and practice. London : Bowker.

LAVE, J. (1991) Situating learning in communities of practice. Julkaisussa: Perspectives on socially shared cognition. Resnick, L.B., Levine, J.M. \& Teasley, S.D. (Eds.) Washington, DC : American Psychological Association.

LEHTINEN, E. \& Rui, E. (1996) Computer supported complex learning : an environment for learning experimental methods and statistical inference. Machine Mediated Learning (5):3-4, 149-175.

LOGAN, E. (1990) Cognitive styles and online behavior of novice searching. Information Processing and Management (26):4, 503-510.

MEADOWS, C.T., Hewett, T.T. \& Aversa, E.S. (1982) A computer intermediary for interactive database searching. I. Design. II Evaluation. Journal of the American Society for Information Science (33):5, 325-332; (33):6, 357-364.

MANNINEN, J. (2000) Kurssikoulutuksesta oppimisympäristöihin - aikuiskoulutuskäytäntöjen kehityslinjoja. Julkaisussa: Aikuiskoulutus verkossa : verkkopohjaisten oppimisympäristöjen teoriaa ja käytäntöä. Toimittaneet Janne Matikainen \& Jyri Manninen. Helsinki : Helsingin yliopiston Lahden tutkimus- koulutuskeskus. s. 29-42.

MANNINEN, J. \& Pesonen, S. (1997) Uudet oppimisympäristöt. Aikuiskasvatus 4, 267-274. 
NEUMAN, D. (1997) Learning and the digital library. Library Trends (45):4, 687-707.

PALINCSAR, A. \& Brown, A. (1984) Reciprocal teaching of comprehension fostering and monitoring activities. Cognition and Instruction (1):2, 117175.

PANTZAR, E. (1995) Theoretical views on changing learning environments. Julkaisussa: Theoretical foundations and applications of modern learning environments edited by Eero Pantzar ...[et al.] Tampere : Tampereen yliopisto tietokonekeskus/ hypermedialaboratorio. s. 85-102.

PANTZAR, E. (1998) Oppimisympäristöjä etsimässä: kolme tosikertomusta elävästä elämästä ja päätöstarina. Tampere: Taju.

PERKINS, D.N. (1991) Technology meets constructivism: Do they make a marriage. Educational Technology (31):5, 18-23.

RESNICK, L.B., Levine, J.M. \& Teasley, S.D. (Eds.) (1991) Perspectives on socially shared cognition. Washington, DC : American Psychological Association.

SARACEVIC, T. (1996) Relevance reconsidered '96. Proceedings CoLIS 2 Second international conference on conceptions of library and information science : intergation in perspective, s. 201-218.

SARACEVIC, T. \& Kantor, P. (1988) A study of information seeking and retrieving I-III. Journal of the American Society for Information Science (39):3, 161-176, 177-196, 197-216.

SCARDAMALIA, M. \& Bereiter, C (1994) Computer support for knowledge building communities. Journal of the Learning Sciences 3, 265-283.

SCHAMBER, L. (1994) Relevance and information behavior. Julkaisussa: Annual Review of information Science and Technology (ARIST). Ed by Martha E. Williams. Medford: ASIS \& Learned Information, s. 3-48.

SORMUNEN, E. et al. (1998) The IR Game: a tool for rapid query analysis in Cross-language IR experiments. Julkaisussa : Proceedings of The Joint Workshop on Cross Language Issues inArtificial Intelligence \& Issues of Cross Cultural Communication, 24 November, 1998, Kent Ridge Digital Labs, Singapore.

SPINK, A., Bateman, J. \& Jansen, B. J. (1998) Searching heterogeneous collections on the Web: behaviour of Excite users. Information Research: an electronic journal [online] (4): 2 päivitetty 12.10.1998 [viitattu 23.5.2000]. Saatavilla wwwmuodossa: URL:http://www.shef.ac.uk/ is/publications/infres/paper53.htm>

STIRLING, K. H. (1984) A micro-based emulator for on-line search services. Drexel Library Quarterly (20):4, 87-97.

TELLA, S. (1997) Tietokoneperustaisesta opetuksesta verkostopohjaiseen oppimiseen. Aikuiskasvatus 4, 258-266.

WANG, P., Hawk, W.B. \& Tenopir, C. (2000) Users' interaction with worl wide web resources: an exploratory study using holistic approach. Information Processing and Management (36):2, 229254 .

\section{Liite 1}

Eläytymismenetelmässä käytetyt kehyskertomukset

Opiskelija käyttää informaatiotutkimuksen tiedonhaun perusteiden kurssin harjoituksessa "Tiedonhakupeliä" ja tekee tiedonhakuja sekä kuvatietokannasta että sanomalehtiartikkelitietokannasta. Kyseisen harjoituskerran jälkeen hän huomaa oppineensa paljon tiedonhausta. Käytä mielikuvistustasi ja kirjoita pieni - realistinen ja tapahtumiltaan mahdollinen - kertomus tai kuvaus siitä, mikä edisti oppimista “Tiedonhakupeliä” käytettäessä.

Opiskelija käyttää informaatiotutkimuksen tiedonhaun perusteiden kurssin harjoituksessa "Tiedonhakupeliä" ja tekee tiedonhakuja sekä kuvatietokannasta että sanomalehtiartikkelitietokannasta. Kyseisen harjoituskerran jälkeen hän huomaa oppimisensa olleen erityisen vähäistä. Käytä mielikuvistustasi ja kirjoita pieni - realistinen ja tapahtumiltaan mahdollinen - kertomus tai kuvaus siitä, mikä esti oppimista “Tiedonhakupeliä” käytettäessä.

Artikkeli saapui toimitukseen 7.3.2000.

Se hyväksyttiin julkaistavaksi toimituskunnan kokouksessa 21.8.2000. 